\title{
A Putative Defective Interfering RNA from Bean pod mottle virus
}

Vijaya P. Sundararaman, Wyeth-Ayerst Research, 145 King of Prussia Road, Radnor, PA 19087; and Martina V. Strömvik and Lila O. Vodkin, Department of Crop Sciences, Edward R. Madigan Laboratory, University of Illinois at Urbana-Champaign, Urbana 61801

\begin{abstract}
Sundararaman, V. P., Strömvik, M. V., and Vodkin, L. O. 2000. A putative defective interfering RNA from Bean pod mottle virus. Plant Dis. 84:1309-1313.

A putative defective interfering (DI) RNA from the Bean pod mottle virus (BPMV) was discovered by screening of random cDNA clones in a soybean cDNA library. This was unexpected because the library was constructed from mRNA of visually healthy soybean pods. The insert in the cDNA clone, VS-16, is not present in the soybean genome but showed strong mRNA expression in pod tissue of soybean and in bean leaf beetles collected in the field. Analysis of the VS16 sequence reveals that it has significant homology to the 3.66-kb BPMV RNA-2. A 2-kb region has been deleted in VS-16, and other regions of the viral RNA genome have been rearranged to yield a putative defective interfering RNA (DI RNA) of $1.35 \mathrm{~kb}$. The three regions of VS-16 are $95.8,77.8$, and $85.6 \%$ identical at the nucleotide level to the corresponding regions of BPMV RNA-2. This is the first report of a DI RNA from the comovirus group of plant viruses. It may be helpful in antivirus efforts for soybean, especially since there are increasing numbers of reports of BPMV in soybeans in the midwestern United States.
\end{abstract}

Additional keywords: DI RNA virus genome

Defective interfering (DI) RNAs are deletion mutants of the parental virus genome and are usually dependent on the parental helper virus for their multiplication in host cells. Since DI RNAs replicate at the expense of the parent virus, they are generally found to interfere with the normal replication of the parent virus (31) and thus have been implicated in the reduction of infectious viral accumulation and symptom development. DI RNAs have been found to occur ubiquitously in animal virus infections (21). Many reports of DI RNAs in plant virus groups also exist in current literature. DI RNAs have been very well documented in many viruses such as the tombusvirus $(1,8,29)$, carmovirus (13), geminivirus (5), potexvirus (36), bromovirus (22), and cucumovirus (6) groups. Here we report the existence of putative DI RNAs in the comovirus group of plant viruses.

Bean pod mottle virus (BPMV), a typical comovirus, has a bipartite positivesense single-stranded RNA genome (7). The virus contains three sedimenting components. The bottom component consists of

Corresponding author: L. O. Vodkin

E-mail: 1-vodkin@uiuc.edu

The nucleotide sequence data will appear in the GenBank, EMBL, and DDBJ Nucleotide Sequence Databases under accession no. AJ269536.

Accepted for publication 5 September 2000.

Publication no. D-2000-1019-01R

(C) 2000 The American Phytopathological Society one single RNA molecule (RNA-1 or B RNA), the middle component consists of another RNA molecule (RNA-2 or M RNA), and the top (T) component consists of empty particles. The RNAs are polyadenylated, and RNA-1 (B RNA) is responsible for replication, while RNA-2 (M RNA) encodes the coat proteins (19). The complete nucleotide sequences of both BPMV RNA-1 and RNA-2 have been determined $(2,15)$. BPMV causes bean pod mottle disease, first recorded in Arkansas, North Carolina, and Louisiana (27). It is sap-transmissible and infects legumes, with certain chrysomelid beetles as vectors (7).

\section{MATERIALS AND METHODS}

Preparation of total RNA and mRNA. Total RNA was extracted from soybean tissues of various Clark isolines, including young pods, old pods, and other tissues. Lyophilized tissues were ground with sterile sand to a fine powder, and $12 \mathrm{ml}$ of extraction buffer (100 mM Tris- $\mathrm{HCl}, \mathrm{pH}$ 9.0, $20 \mathrm{mM}$ EDTA [ $\left.\mathrm{Na}_{2}\right], 1 \% \mathrm{wt} / \mathrm{vol}$ sarkosyl, $200 \mathrm{mM} \mathrm{NaCl}, 5 \mathrm{mM}$ DTT) was added (17). The crude extract was immediately poured into an equal volume of phenolchloroform $(1: 1, \mathrm{vol} / \mathrm{vol})$ and vortexed for $2 \mathrm{~min}$. The aqueous phase was separated from the organic phase by centrifugation, and an equal volume of chloroform was added to the aqueous phase, vortexed, and phases were again separated by centrifugation. After the final spin, one-third volume of $8 \mathrm{M} \mathrm{LiCl}$ was added to the aqueous phase to a final concentration of $2 \mathrm{M}$, and the solution was held at $4^{\circ} \mathrm{C}$ overnight to precipitate RNA. The RNA was pelleted and washed twice with $2 \mathrm{M} \mathrm{LiCl}$, dried briefly, dissolved in RNase free water, and centrifuged briefly to pellet insoluble material. The supernatant was transferred, and the RNA ethanol was precipitated and centrifuged. The pellet was dried, resuspended in water, and stored at $-70^{\circ} \mathrm{C}$. Total RNA from bean leaf beetles was extracted in the same manner.

Poly(A) RNA was isolated from $500 \mu \mathrm{g}$ of young pod total RNA with the Poly(A) tract mRNA isolation system using directions given by the manufacturer (Promega, Madison, WI). The pods were collected from soybean plants (Clark isoline, UC 75) grown in the field (South Farms, University of Illinois). The mRNA eluate was frozen at $-20^{\circ} \mathrm{C}$ for $10 \mathrm{~min}$ and then dried down in a speed-vac. The RNA pellet was then dissolved in $15 \mu$ l of RNase free water and stored at $-70^{\circ} \mathrm{C}$. The cDNA library was constructed using the Superscript Lambda system kit (Life Technologies Inc., Gaithersburg, MD) with the procedure described by Strömvik et al. (33).

Polymerase chain reaction (PCR) amplification and isolation of amplified cDNA insert fragments. PCR was used to identify bacteriophage clones in the cDNA library that contained cDNA inserts. Primary phage plaques were picked from the library and resuspended in $500 \mu \mathrm{l}$ of SM

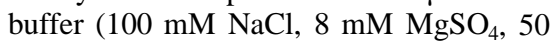
$\mathrm{mM}$ Tris- $\mathrm{HCl}, \mathrm{pH} 7.5,0.01 \%$ gelatin) and $20 \mu \mathrm{l}$ of chloroform. Aliquots of individual phage stocks ( $5 \mu$ volume) were subjected to quick freeze-thaw in liquid nitrogen three times. These DNA samples were then amplified by PCR using M13 forward and reverse primers. PCR was carried out in 25- $\mu$ l volume reactions with Taq DNA polymerase (Life Technologies) using a PTC-100 Programmable Thermal Controller (MJ Research Inc., Watertown, MA). The temperature cycle was $2 \mathrm{~min}$ in denaturation at $96^{\circ} \mathrm{C}$ followed by 39 cycles of $20 \mathrm{~s}$ denaturation at $96^{\circ} \mathrm{C}, 1 \mathrm{~min}$ primer annealing at $36^{\circ} \mathrm{C}$, and $2 \mathrm{~min}$ in extension at $72^{\circ} \mathrm{C}$. This was followed by a final 7 min in extension at $72^{\circ} \mathrm{C}$. The products were held at $4^{\circ} \mathrm{C}$ until they were loaded onto a $0.7 \%$ agarose gel.

The PCR products were then electrophoresed through a $0.7 \%$ agarose gel in $1 \times \mathrm{TA}$ (40 mM Tris, acetic acid to $\mathrm{pH} 7.8$ ) (16). Gels were stained with ethidium bromide and photographed. The fragments of interest were cut out of the agarose gel, and the DNA was purified by passing through a $0.2-\mu \mathrm{m}$ syringe filter (Gelman Sciences 
\#4192, Ann Arbor, MI) using a $3-\mathrm{cm}^{3}$ syringe as described (14).

Northern blotting procedures. Standard laboratory procedures were used for RNA gel electrophoresis, blotting, probe preparation, and hybridization as described $(3,16,34)$.

In vivo excision of cDNA clones and sequence analysis. Phage plaques were picked from the primary library and resuspended in $500 \mu$ l of SM buffer $(100 \mathrm{mM}$

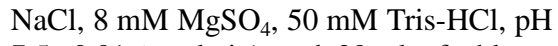
$7.5,0.01 \%$ gelatin) and $20 \mu \mathrm{l}$ of chloroform. For excision of a cDNA clone from lambda ZipLox phage into plasmid pZL1, $25 \mu \mathrm{l}$ of the supernatant from the soaked plaque was mixed with $100 \mu \mathrm{l}$ of Escherichia coli $\mathrm{DH} 10 \mathrm{~B}(\mathrm{ZIP})$ cells and incubated at room temperature for $5 \mathrm{~min}$. The entire mixture was then spread onto an LB plate containing $10 \mathrm{mM} \mathrm{MgCl}$ and $100 \mu \mathrm{g}$ of ampicillin per $\mathrm{ml}$. The plate was incubated

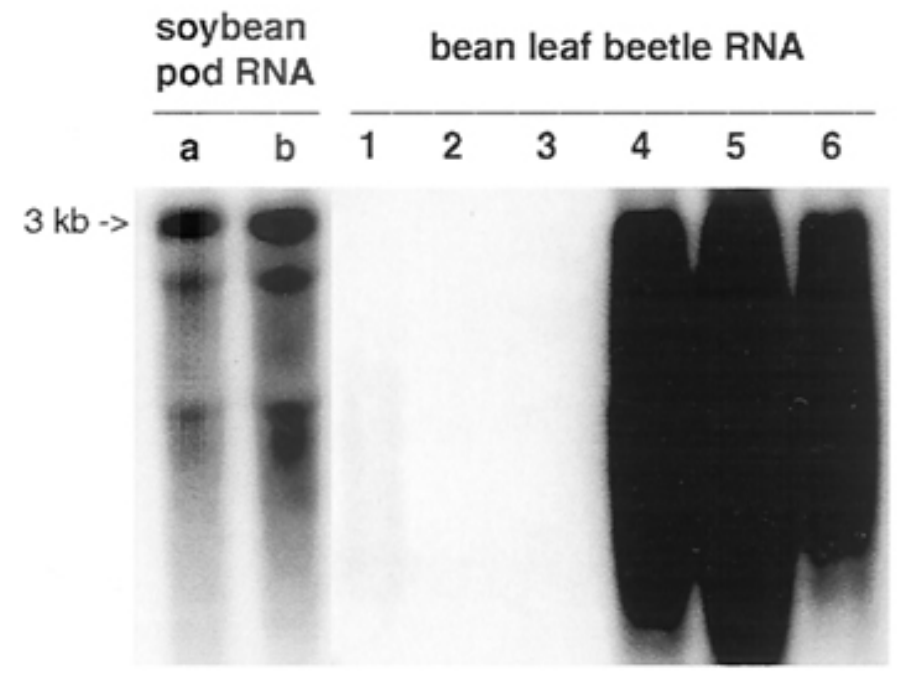

Fig. 1. Northern blot test showing the presence of Bean pod mottle virus (BPMV) RNA in total RNA from soybean pods (lanes a and b) and bean leaf beetles (lanes 1 to 6). Total RNA (10 $\mu \mathrm{g}$ ) was run on a denaturing $1.2 \%$ agarose gel, blotted, and probed with a $1.35-\mathrm{kb} \mathrm{cDNA}$ insert isolated from plasmid pVSZL-16. The ethidium bromide staining of the gel showed equal amounts of ribosomal RNA in all of the beetle samples (data not shown). The BPMV RNA is present in total RNA from both mature (lane a) and young (lane b) pods of soybean and in three of the six bean leaf beetle samples (lanes 4 to 6). This shows that BPMV is present in the bean leaf beetle population in Illinois.

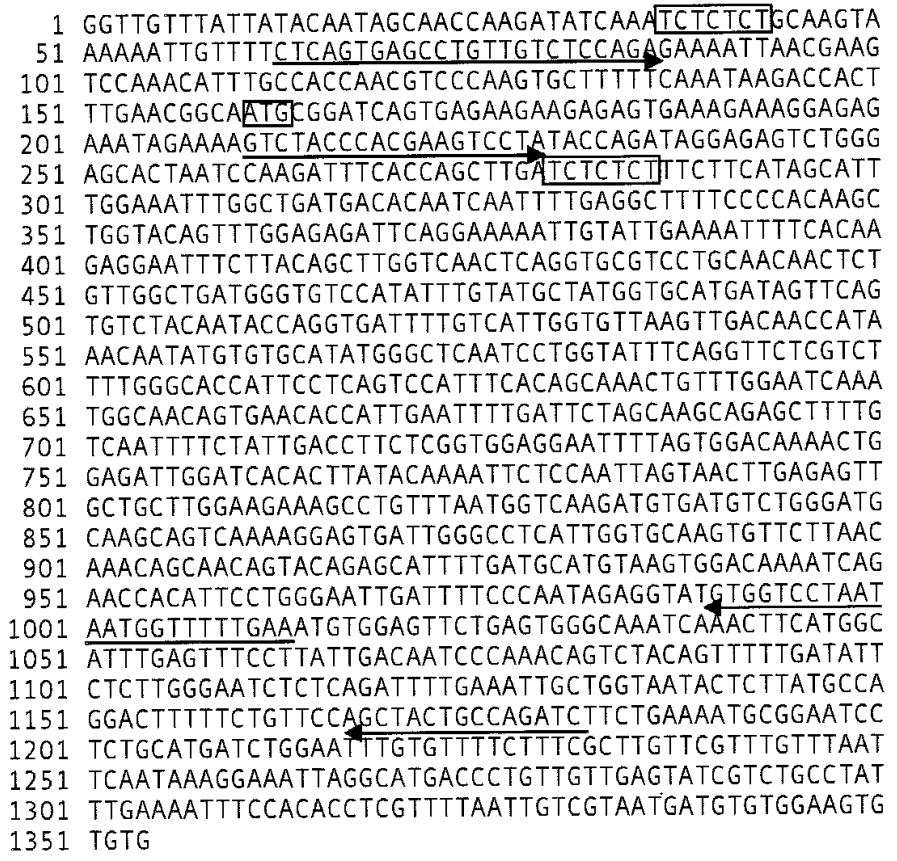

Fig. 2. DNA sequence of the 1.35-kb cDNA insert VS-16. The putative start codon AUG and uridine rich fragments have been boxed. The sequencing primers used for primer walking were M13 reverse and forward primers and additional custom-designed primers annealing at 63 to 86 (VS16-11F), 211 to 230 (VS16-12F), 1350 to 1330 (VS16-51R), 1181 to 1167 (VS16-52R), and 1012 to 986 (VS1653R), marked by arrows. overnight at $37^{\circ} \mathrm{C}$. Plasmid DNA was extracted from selected bacterial colonies (39), and restriction digestion with NotI and SalI yielded a $4.3-\mathrm{kb}$ pZL1 vector fragment and a unique cDNA insert. For sequencing, plasmid DNA was extracted via the Wizard maxi-prep DNA purification system following directions given by the manufacturer (Promega). Doublestranded DNAs were sequenced using Sequenase version 2.0 (United States Biochemical, Cleveland, $\mathrm{OH}$ ) and partly using the automated DNA sequencing system (Model 373, Applied Biosystems, Foster City, CA). The nucleotide sequence of the cDNA insert of VS-16 was obtained by sequencing approximately 750 to $1,000 \mathrm{bp}$ from both the $5^{\prime}$ and $3^{\prime}$ ends. Sequence data were analyzed using the GCG software package (Genetics Computer, Inc., Madison, WI) and NCBI BLAST e-mail server <http://www.ncbi.mlm.nih.gov/BLAST/>.

\section{RESULTS AND DISCUSSION}

Detection of a naturally occurring putative DI RNA of BPMV. Screening of a soybean pod cDNA library led to isolation of a clone, pVSZL-16, that had significant sequence similarity to the BPMV RNA-2 (Accession no. M62738). The pVSZL-16 clone was found by screening isolated random clones by Northern blotting and subsequent sequencing as described (33). The clone did not hybridize to Southern blots containing soybean genomic DNA from the same line (Clark) (data not shown). These results strongly suggest that the insert, VS-16, is not part of the plant genome and is in fact of viral origin.

A Northern blot of total RNA extracted from pods of field grown soybean plants and from bean leaf beetles (Coleoptera trifurcata) is shown Figure 1. The probe is the radiolabeled insert VS-16 of the cDNA clone. An intense positive fragment of approximately $3 \mathrm{~kb}$ and additional smaller RNA fragments are seen from the pod RNA. The intensity of the positive RNA in the pods was surprising since the total RNA on the blot was extracted from pods of apparently healthy plants. For that reason, the beetles, which are known vectors of BPMV, were collected from soybean fields at various sites in Illinois and RNA was extracted for detection of BPMV. The beetle RNA show either an intense positive or a clear negative signal on the blot, although the ribosomal RNA bands on the gel (not shown) showed equal loading of RNA.

The complete 1.35-kb nucleotide sequence of the VS-16 cDNA insert is shown in Figure 2. The VS-16 sequence showed a high percentage of similarity to the middle component RNA (RNA-2) of BPMV (15). Figure 3 shows part of the putative peptide sequence of VS-16 aligned with the last part of the BPMV large coat protein and the first part of the adjacent small coat protein that is encoded on RNA-2 
(Accession no. M62738). The homologous region of VS-16 shows $85.6 \%$ similarity to the amino acid sequence of BPMV's coat proteins. The $1.35-\mathrm{kb}$ clone was included in the pod cDNA library because of the polyadenylation of its RNA. Sequence analysis showed that VS-16 contains a mosaic of the BPMV RNA-2 genome. The VS-16 sequence can be roughly divided into three regions that match BPMV RNA2 regions as is depicted in Figure 4. While two regions of VS-16 (regions 1 and 3 in the figure) showed 95.8 and $85.6 \%$ sequence identity to different parts of the positive strand of BPMV RNA-2, a third 228-bp region (region 2 in the figure) showed $77.8 \%$ sequence identity to the negative strand of RNA-2. Also, VS-16 has a 2-kb internal deletion of BPMV RNA-2, and it appears to be a putative DI RNA.

Several models have been suggested to explain the generation of DI RNAs. A general model proposed for DI RNA synthesis involves production of an RNA molecule with one or more internal deletions by an aberrant transcriptional mechanism. Sometimes, the defective RNA molecule contains a mosaic sequence as a result of the viral replicase hopping to a different part of the template or switching to another template strand, resulting in a rearrangement of the viral genome sequence $(11,12,21)$. Also, a mechanism of DI generation where a nascent positive strand attached to the ribonucleoprotein complex leaves the template and reattaches downstream by hybridization to a complementary sequence has been speculated (4).

Viral polymerase is known to stutter at short uridine segments (23). Therefore, one model proposes that DI RNAs are generated when the viral polymerase pauses at uridine-rich clusters in the template and reinitiates synthesis at a different site (4). Our observations agree with this model to a certain level. We noticed that the junctions of the deletions and/or rearrangements contain short 7-base-long uridine rich segments. These have been boxed in Figure 2. Many plant DI RNAs that contain internal deletions of the parental virus genome have been reported $(8,13,26,28$, $36,38)$. Here we report for the first time a plant DI RNA containing a rearranged sequence arising from a polymerase that switches from using a negative strand to using a nascent positive strand as its template.

Comparisons of the RNA-2 sequence to the DI RNA sequence and the mechanism of DI accumulation. The RNA- 2 of BPMV consists of 3,662 nucleotides excluding the poly(A) tail, and it contains a single long open reading frame (ORF) (19). The RNA is translated into polyproteins, which upon cleavage yield the functional proteins. Translation of BPMV RNA-2 is initiated using either the AUG codon at position 455 or an in-phase AUG codon downstream at position 761 , resulting in a smaller protein product. After synthesis of the polyproteins encoded by the RNA-2, the protease encoded by the RNA-1 cleaves the polyproteins twice to yield a large $41 \mathrm{~K}$ viral coat protein (L), a small $22 \mathrm{~K}$ viral coat protein (S), and a $50 \mathrm{~K}$ or $38 \mathrm{~K} \mathrm{~N}$-terminal protein, depending on whether the large or small polyprotein is processed. The $\mathrm{N}$-terminal protein is a putative transport (Tra) protein that is responsible for cell-to-cell movement of the virus. BPMV RNA has a $4-\mathrm{kDa}$ protein (VPg) that is covalently linked to the $5^{\prime}$ terminus. The genome organization of BPMV RNA-2 is shown in Figure 4B.

Sequence comparisons with BPMV RNA-2 show that DI RNA VS-16 contains a deletion in the large viral coat protein (L) and a deletion combined with a rearrangement in the N-terminal protein (Fig. 4). The entire $3^{\prime}$ terminus of the BPMV RNA2 has been retained. The AUG codon at position 161 may initiate translation in the DI RNA (Fig. 2). The deletions are inframe so that even if the putative AUG codon comes from region 2, after 43 amino acid residues there is an ORF that is homologous to the last part of the large coat protein and, with the exception of one stop codon, also extends into the small coat protein sequence. There are additional stop codons but no frameshift in the small coat protein sequence. The maintenance of a reading frame to retain translatability is thought to play an important role in increasing message stability and accumulation levels of the DI RNA (35). Retention of an intact ORF in the DI RNA is also found in a few other viruses such as the Clover yellow mosaic virus (37), Broad bean mosaic virus (22), and the Poliovirus (10), and translatability of a DI RNA is speculated to increase its competitiveness. However, the reading frame in VS-16 is prematurely interrupted by stop codons. This could be due to the sequence of the progenitor virus diverging in the Illinois BPMV strain. The first stop is situated toward the end of the large coat protein, and it is the small coat protein that has most of the stop codons (and also lower similarity than the large coat protein region). It is possible that the progenitor virus can manage with a truncated large coat protein only, and this may be the reason that BPMV in Illinois is not as virulent.

Modulation of disease symptoms by DI RNAs in infected host plants. Many DI RNAs have been shown to interfere with symptom development caused by the virus. Most of the reported interference is in the form of amelioration of the virus by DI RNAs, manifested as symptom attenuation. The DI RNAs of Tomato bushy stunt virus (TBSV) (8), Cymbidium ringspot virus (CyRSV) (1), and Cucumber necrosis virus (CNV) (25) decrease severity of symptoms. Attenuation of symptoms is thought to be influenced by a reduction in the accumulation of genomic RNA. This is mainly due to competition of DIs with the nondefective virus for available replicase (9). Later studies with TBSV DI RNAs showed that the protective effect of TBSV DIs could also be due to an inhibition in the expression of p22 (responsible for cell-to-cell movement) and p19 (associated with tissue necrosis) proteins in addition to the reduction in accumulation of viral genomic RNA (32). Our studies show similar results. Host plants showed no symptoms of infection, and detailed sequence analysis of DI VS-16 revealed an inhibition (by deletion) in the expression of

42 FFIAFGNLADDTINFEAFPHKLVQFGEIQEKLY*KFSQEEFLTAWSTQVR 91

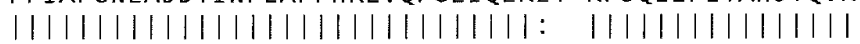

710 FFIAFGNLADDTINFEAFPHKLVQFGEIQEKVVLKFSQEEFLTAWSTQVR 759

92 PATTLLADGCPYLYAMVHDSSVSTIPGDFVIGVKLTTINNMCAYGLNPGI 141 || || ||||||||||||||||||||||||||||||||||,|:||||||||||||

760 PATTLLADGCPYLYAMVHDSSVSTIPGDFVIGVKLTIIENMCAYGLNPGI 809

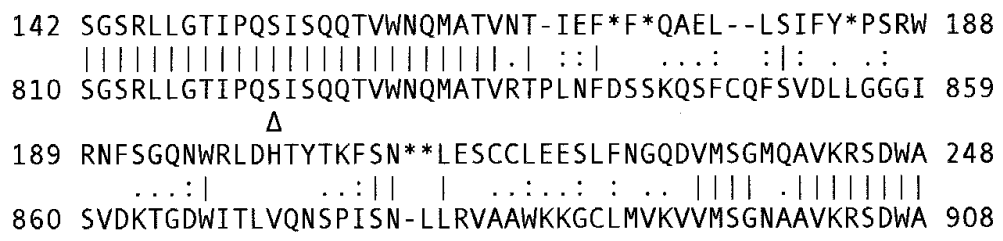

\section{SLVQVFLTNSNSTEHFDACKWTKSEPHSWELIFPIEVCGPNNGF 292 || ||||||||||||||||||:|||||||||||||||||||||||||| \\ 909 SLVQVFLTNSNSTEHFDACRWTKSEPHSWELIFPIEVCGPNNGF 952}

Fig. 3. Peptide sequence similarity between VS-16 and Bean pod mottle virus (BPMV). The reading frame of VS-16, amino acids 42 to 292 beginning at the putative AUG translational initiation codon at nucleotide position 161, was compared with the last part of the large coat protein and to the adjacent first part of the small coat protein of BPMV (accession no. M62738, amino acid residues 710 to 952). The symbols used in the figure signify the following: stars are stops, dashes are gaps, stripes indicates identity, two dots high similarity, one dot a weak similarity, and the $\Delta$ points at the first amino acid residue of the small coat protein. 
the N-terminal protein that is thought to be involved in the transport of the virus (Fig. 4B). Inhibition of expression of the large coat protein may not seriously affect the accumulation of DI RNAs, as similar observations have been reported with other DIs. DI RNAs of the CyRSV and TBSV are known to be inefficiently packaged $(1,20)$. Also, CNV can replicate and move systemically in the absence of a functional coat protein (18), and the gene is not required for the accumulation or systemic movement of DIs (24).

Future perspectives for the use of this DI RNA. Infection by BPMV has commonly been reported as a problem in the southern United States, and recently its occurrence has been more frequent in Illinois (Glen Hartman, personal communication). The BPMV in Illinois may be a weaker strain, and the sequence divergence in the small coat protein between BPMV and VS-16 reflects just that the progenitor virus of the DI BPMV is a different strain from that which causes problems in the south.

Nicotiana benthamiana has been rendered protected against tombusviruses at a broad range after being transformed with DI RNAs (30). Since most DI RNAs, with the exception of Turnip crinkle virus (TCV) (14), Cucumber mosaic virus

A

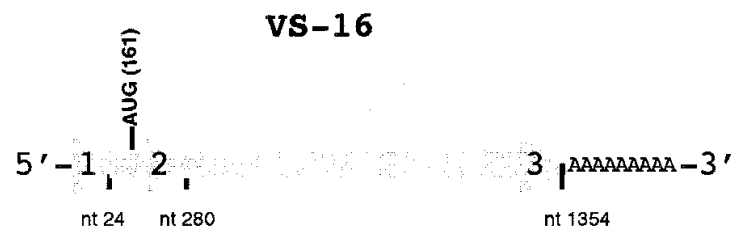

B

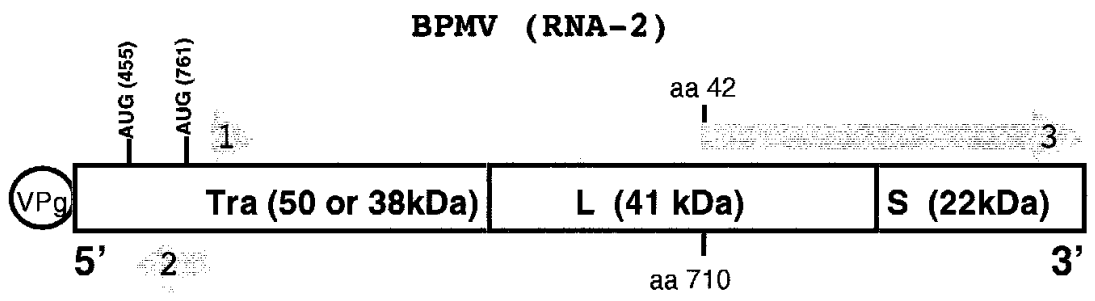

Region (\% identity to BPMV)

1) $95.8 \%$
2) $77.8 \%$
3) $85.6 \%$

Fig. 4. (A) The three regions of the insert VS-16 based on nucleotide sequence similarity with Bean pod mottle virus (BPMV). Region 1 spans bases 1 to 24 in VS-16 and corresponds to bases 535 to 558 in BPMV (95.8\% identity), region 3 spans bases 282 to 1354 in VS-16 and corresponds to 2577 to 3655 in BPMV (85.6\% identity), and region 2 spans bases 47 to 275 in VS-16, which corresponds to the reverse complement of bases 296 to 515 in BPMV (77.8\% identity). $\mathrm{nt}=$ nucleotide. (B) Overview of genome organization of BPMV RNA-2. Tra is a putative transport protein, and L and S are the large and small coat proteins, respectively. VPg is a 4-kDa protein that is linked to the $5^{\prime}$ terminal. The three regions, 1, 2, and 3, from VS-16 are placed to indicate where they correspond on BPMV. aa = amino acid. segment. Cell 28:303-313.

5. Frischmuth, T., and Stanley, J. 1991. African cassava mosaic virus DI DNA interferes with the replication of both genomic components. Virology 183:539-544.

6. Graves, M. V., and Roossinck, M. J. 1995. Characterization of defective RNAs derived from RNA 3 of the Fny strain of cucumber mosaic cucumovirus. J. Virol. 8:4746-4751.

7. Hartman, G. L., Sinclair, J. B., and Rupe, J. C. 1999. Compendium of Soybean Diseases. 4th ed. American Phytopathological Society, St. Paul, MN.

8. Hillman, B. I., Carrington, J. C., and Morris, T. J. 1987. A defective interfering RNA that contains a mosaic of a plant virus genome. Cell 51:427-433.

9. Jones, R. W., Jackson, A. O., and Morris, T. J. 1990. Defective interfering RNAs and elevated temperatures inhibit replication of tomato bushy stunt virus in inoculated protoplasts. Virology 176:539-545.

10. Kuge, S., Saito, I., and Nomoto, A. 1986 Primary structure of poliovirus defective-interfering particle genomes and possible generation mechanism of particles. J. Mol. Biol. 192:437-487.

11. Lai, M. C. 1992. RNA recombination in animal and plant viruses. Microbiol. Rev. 56:6179.

12. Lazzarini, R. A., Keene, J. D., and Schubert, M. 1981. The origins of defective interfering particles of the negative-strand RNA viruses. Cell 26:145-154.

13. Li, X. H., Heaton, L. A., Morris, T. J., and Simon, A. E. 1989. Turnip crinkle virus defective interfering RNA intensify viral symptoms and are generated de novo. Proc. Natl. Acad. Sci. USA 86:9173-9177.

14. Lu, Z., Templer, M., and Nielsen, B. 1994. Rapid method for recovery of DNA from agarose gels. BioTechniques 16:400-402.

15. Macfarlane, S. A., Shanks, M., Davies, J. M., Zlotnik, A., and Lomonossoff, G. P. 1991. Analysis of the nucleotide sequence of bean pod mottle virus middle component RNA. Virology 183:405-409.

16. Maniatis, T., Fritsch, E. F., and Sambrook, J. 1982. Molecular Cloning: A Laboratory Manual. Cold Spring Harbor Laboratory, Cold Spring Harbor, NY.

17. McCarty, D. R. 1986. A simple method for extraction of DNA from maize tissue. Maize Genet. Coop. Newsl. 60:61.

18. McLean, M. A., Hamilton, R. I., and Rochon, D. M. 1993. Symptomatology and movement of a cucumber necrosis virus mutant lacking the coat protein protruding domain. Virology 193:932-939.

19. Moore, B. J., and Scott, H. A. 1971. Properties of a strain of bean pod mottle virus. Phytopathology 61:715-716.

20. Morris, T. J., and Hillman, B. I. 1989. Defective interfering RNAs of a plant virus. Pages 185-197 in: UCLA Symposia on Molecular and Cellular Biology. New series: Vol. 101. Molecular Biology of Plant-Pathogen Interactions. B. Staskawicz, P. Ahlquist, and O Yoder, eds. A. R. Liss, New York.

21. Perrault, J. 1981. Origin and replication of defective interfering particles. Curr. Top. Microbiol. Immunol. 93:151-207.

22. Pogany, J., Romero, J., and Bujarski, J. J. 1997. Effect of $5^{\prime}$ and $3^{\prime}$ terminal sequences, overall length, and coding capacity on the accumulation of defective RNAs associated with broad bean mottle bromovirus in planta. Virology 228:236-243.

23. Robertson, J. S., Schubert, M., and Lazzarini, R. A. 1981. Polyadenylation sites for influenza virus mRNA. J. Virol. 38:157-163.

24. Rochon, D. M., Finnen, R. L., and Sit, T. L. 1994. Coat protein of cucumber necrosis virus 
is not required for efficient generation or accumulation of defective interfering RNAs. J. Gen. Virol. 75:2505-2508.

25. Rochon, D. M., and Johnston, J. C. 1991. Infectious transcripts from cloned cucumber necrosis virus cDNA. Evidence of a bifunctional subgenomic mRNA. Virology 181:656665.

26. Romero, J., Huang, Q., Pogany, J., Bujarski, J. J. 1993. Characterization of defective interfering RNA components that increase symptom severity of broad bean mottle virus infections. Virology 194:576-584.

27. Ross, J. P. 1987. Viral and bacterial diseases. Pages 729-755 in: Soybeans: Improvement, Production and Uses. J. R. Wilcox, ed. ASA, CSSA, and SSSA, Madison, WI.

28. Rubino, L., Burgyan, J., Grieco, F., and Russo, M. 1990. Sequence analysis of cymbidium ringspot virus satellite and defective interfering RNAs. J. Gen. Virol. 71:16551660.

29. Rubino, L., Burgyan, J., and Russo, M. 1995. Molecular cloning and complete nucleotide sequence of carnation Italian ringspot tom- busvirus genomic and defective interfering RNAs. Arch. Virol. 140:2027-2039.

30. Rubio, T., Borja, M., Scholtof, H. B., Feldstein, P. A., Morris, T. J., and Jackson, A. O. 1999. Broad-spectrum protection against Tombusviruses elicited by defective interfering RNAs in transgenic plants. J. Virol. 73:5070-5078.

31. Schlesinger, S. 1988. The generation and amplification of defective interfering RNAs. Pages 167-185 in: RNA Genetics. Retroviruses, Viroids and RNA Recombination. Vol. 2. E. Domingo, J. J. Holland, and P. Ahlquist, eds. CRC Press, Boca Raton, FL.

32. Scholthof, K. B., Scholthof, H. B., and Jackson, A. O. 1995. The effect of defective interfering RNAs on the accumulation of tomato bushy stunt virus proteins and implications for disease attenuation. Virology 211:324328 .

33. Strömvik, M. V., Sundararaman, V. P., and Vodkin, L. O. 1999. A novel promoter from soybean that is active in a complex developmental pattern with and without its proximal 650 base pairs. Plant Mol. Biol. 41:217-231.
34. Todd, J. J., and Vodkin, L. O. 1996. Duplications that suppress and deletions that restore expression from a soybean multigene family. Plant Cell 8:687-699.

35. Vancanneyt, G., Rosahl, S., and Wilmitzer, L. 1990. Translatability of a plant mRNA strongly influences its accumulation in transgenic plants. Nucleic Acids Res. 18:29172921

36. White, K. A., Bancroft, J. B., and Mackie, G. A. 1991. Defective RNAs of clover yellow mosaic virus encode nonstructural / coat protein fusion products. Virology 183:479-486.

37. White, K. A., Bancroft, J. B., and Mackie, G. A. 1992. Coding capacity determines in vivo accumulation of a defective RNA of clover yellow mosaic virus. J. Virol. 66:3069-3076.

38. White, K. A., and Morris, T. J. 1994. Nonhomologous RNA recombination in tombusviruses: Generation and evolution of defective interfering RNAs by stepwise deletions. J. Virol. 68:14-24.

39. Zhou, C., Yang, Y., and Jong, A. Y. 1990. Mini-prep in ten minutes. BioTechniques 8:13-14. 